\title{
PEMBERDAYAAN SEKOLAH BUDI MULIA BALIKPAPAN MELALUI EDUKASI DAN AKSI PEMBUATAN KOMPOS DENGAN METODE TAKAKURA
}

\section{Muhammad Nurhidayatur Rozikin ${ }^{1}$, Muhammad Kamaluddin², Rachmat Hidayat ${ }^{3}$, Umi Sholikah ${ }^{3}$}

\author{
${ }^{I}$ Teknik Material dan Metalurgi, Jurusan Ilmu Kebumian dan Lingkungan, Institut Teknologi \\ Kalimantan, Jl. Soekarno-Hatta KM 15, Karang Joang, Balikpapan 76127 \\ ${ }^{2}$ Teknik Sipil, Jurusan Teknologi Sipil dan Perencanaan, Institut Teknologi Kalimantan \\ Jl. Soekarno-Hatta KM 15, Karang Joang, Balikpapan 76127 \\ ${ }^{3}$ Teknik Lingkungan, Jurusan Ilmu Kebumian dan Lingkungan, Institut Teknologi Kalimantan, \\ Jl. Soekarno-Hatta KM 15, Karang Joang, Balikpapan 76127 \\ Email Penulis Korespondensi: salamofficial1@gmail.com
}

\begin{abstract}
Abstrak
Semua proses kehidupan pasti menghasilkan sampah yang jumlahnya akan semakin meningkat seiring dengan peningkatan jumlah penduduk dan beragam aktivitasnya. Sampah merupakan bagian yang tidak dapat terpisahkan dari kehidupan masyarakat terutama di daerah Perkotaan khususnya Balikpapan. Menurunnya kualitas lingkungan menjadi permasalahan yang terus membayangi masyarakat. Tercatat dalam Laporan Kinerja Instansi Pemerintah Dinas Lingkungan Hidup Kota Balikpapan pada tahun 2017, indeks pengangkutan sampah ke TPA terus meningkat. Permasalahan akibat kenaikan jumlah penduduk di Kota Balikpapan namun tidak diimbangi dengan kepeduliaan masyarakatnya dalam menjaga lingkungan sekitarnya. Sekolah Budi Mulia Balikpapan menjadi contoh bahwa kualitas lingkungan menjadi polemik yang harus diatasi. Keterbatasan fasilitas, sarana dan pra sarana, serta minimnya perhatian pemerintah. Sehingga menjadikan Sekolah Budi Mulia termasuk dalam kategori kawasan kumuh dengan sistem pengolahan sampah yang buruk. Dalam rangka menyadarkan pentingnya arti menjaga kualitas lingkungan hidup, maka perlu adanya pemahaman melalui program Edukasi dan Aksi pembuatan kompos dengan metode takakura menggunakan bantuan aktivator EM4. Berdasarkan hasil dari program pemberdayaan yang telah dilaksanakan kegiatan ini berhasil memberi pengetahuan kepada siswa di Sekolah Budi Mulia Balikpapan dalam pengelolaan sampah dengan metode takakura melalui kegiatan kampanye lingkungan serta edukasi dan aksi lingkungan. Sehingga, dapat disimpulkan bahwa kegiatan edukasi dan aksi lingkungan dengan metode takakura dapat menjadi metode yang efektif dalam peningkatan pemahaman dan kepedulian target sasaran terhadap lingkungan di sekitarnya.
\end{abstract}

Kata Kunci - Aksi, Edukasi, Kompos, Pemberdayaan, Takakura

\begin{abstract}
Everything in the life process definitely produces waste. The amount of waste will increase along with the population also increasing and various activities. Waste is an inseparable part of people's lives, especially in urban areas, like Balikpapan. Decreasing environmental quality is a problem that continues to haunt the community. In the Report on the Performance of the Environmental Agency of Balikpapan City in 2017 that community, the index of waste transportation to landfill continues to increase. Problems due to the rising population in Balikpapan but not balanced with the concern of community in maintaining the environment. Budi Mulia Balikpapan School is an example that the quality of environment becomes a polemic that must be overcome. Limited facilities, and the lack attention from goverment make Budi Mulia School include in the catagories of bad waste management
\end{abstract}


system. In order to realize the importance of maintaining environmental quality it is necessary to have an comprehension through an education and composting program with takakura methode using the help of EM4 activators. Based on the results of the empowerment program that has been implemented, this activity succeeded in providing knowledge to students at Budi Mulia Balikpapan School in waste management with takakura methods through environmental campaign activities and environmental education and action. That educational activities and environmental actions using takakura methods can be an effective method of increasing comprehension and awareness of the target towards the surrounding environment.

Keywords - Action, Composting, Education, Empowerment, Takakura

\section{PENDAhUluaN}

Semua proses kehidupan pasti menghasilkan sampah. Jumlahnya akan semakin meningkat seiring dengan peningkatan jumlah penduduk dan beragam aktivitasnya. Peningkatan jumlah penduduk berarti peningkatan jumlah timbulan sampah dan semakin beragam aktivitas berarti semakin beragam jenis sampah yang dihasilkan. Ini berarti kebiasaan membuang harus diubah menjadi mengolah. Konsep yang dapat digunakan dalam mengolah sampah adalah konsep 3R yaitu reduce: mengurangi penggunaan reuse: menggunakan ulang reycle: memodifikasi benda yang tadinya tidak bermanfaat, menjadi bermanfaat.

Sampah merupakan bagian yang tidak dapat terpisahkan dari kehidupan masyarakat terutama di daerah Perkotaan khususnya Balikpapan. Menurunnya kualitas lingkungan hidup menjadi permasalahan yang terus membayangi masyarakat. Tercatat dalam Laporan Kinerja Instansi Pemerintah Dinas Lingkungan Hidup Kota Balikpapan pada tahun 2017 yaitu mengenai pengangkutan sampah ke TPA mengalami kenaikan dengan persentase sebesar $63,02 \%$ di tahun 2016 menjadi 64,79\% di tahun 2017 (Dinas Lingkungan Hidup Kota Balikpapan, 2017). Semua permasalahan ini tidak terlepas dari kenaikan jumlah penduduk di Kota Balikpapan namun tidak diimbangi dengan peningkatan kepeduliaan masyarakatnya dalam menjaga lingkungan hidup di sekitarnya.

Sampah pada dasarnya merupakan suatu bahan yang terbuang atau dibuang dari suatu sumber hasil aktivitas manusia maupun proses proses alam, apabila tidak ditangani secara baik dan benar dari sumber sampah, maka akan menimbulkan masalah terhadap kesehatan, sosial, ekonomi dan keindahan. Untuk mengurangi timbunan sampah dapat dilakukan dengan cara mengolah sampah dari sumbernya. Sampah terutama sampah dapur dapat dikurangi dengan cara mengubahnya menjadi pupuk kompos.

Pemerintah Indonesia telah mengatur mengenai perlindungan dan pengelolaan lingkungan hidup dalam Undang-undang Nomor 32 Tahun 2009 yang didefinisikan sebagai upaya sistematis dan terpadu yang dilakukan untuk melestarikan lingkungan hidup. Selain itu, semua kalangan masyarakat juga memiliki hak dan kesempatan yang sama untuk berperan aktif dalam perlindungan dan pengelolaan lingkungan hidup, tak terkecuali siswa di Sekolah Budi Mulia Balikpapan. Sekolah ini memiliki fasilitas serta sarana dan prasarana yang minim, bahkan lingkungan sekitar sekolah juga termasuk kategori kumuh dengan sistem pengolahan sampah yang buruk.

Sekolah Budi Mulia Balikpapan merupakan sekolah non formal yang telah berdiri sejak tahun 2008 dibawah naungan Yayasan Tunas Alam Cendekia (YTAC) yang terletak di Jl. Proklamasi, Kecamatan Balikpapan Timur, Kota Balikpapan dengan jumlah siswa sebanyak 22 siswa yang sudah tergabung dari jenjang SMP dan SMK. Sekolah Budi Mulia Balikpapan memiliki fasilitas ataupun sarana dan prasana yang sangat minim dengan memiliki satu ruang kelas yang berdinding bambu serta tenaga pengajar yang sedikit yaitu hanya berjumlah 8 orang guru, berakibat pada penghapusan beberapa mata pelajaran tertentu salah satunya yaitu pendidikan lingkungan hidup yang seharusnya didapatkan pada anak-anak yang memasuki jenjang sekolah menengah. Sehingga, anak-anak di Sekolah Budi Mulia ini memiliki pengetahuan yang kurang dalam pendidikan lingkungan hidup terutama mengenai pengelolaan dan kebersihan baik pada diri sendiri ataupun lingkungannya.

Meski memiliki beberapa tempat sampah dari bekas drum dan tempat sampah kecil pengolahan sampah terpadu tidak terlaksana di sekolah Budi Mulia Balikpapan, karena 
terbatasnya pengetahuan para siswa dan guruguru di sana. Walaupun sekolah tersebut merupakan sekolah alam bukan berarti mereka sepenuhnya paham mengenai pendidikan lingkungan hidup, apalagi jika memiliki fasilitas yang terbatas. Hal inilah yang menjadi perhatian kami sebagai Mahasiswa untuk memberikan pengetahuan lebih dan mengubah kebiasaan tidak sehat yang sering dilakukan target mitra. Sehingga, diperlukan sebuah kegiatan terpadu untuk menangani masalah sampah di Sekolah Budi Mulia ini.

Dalam rangka menyadarkan pentingnya arti menjaga kualitas lingkungan hidup dan pengelolaan sampah yang baik, maka perlu adanya pemahaman pengetahuan lingkungan hidup dan pengelolaan sampah di lingkungan pendidikan ataupun masyarakat. Oleh karena itu, kami menawarkan program Pemberdayaan Sekolah Budi Mulia Balikpapan Melalui Edukasi dan Aksi Pembuatan Kompos dengan Metode Takakura. Adapun kegiatan dalam program ini diantaranya yaitu pemberian materi lingkungan hidup, pengelolaan sampah, kunjungan ke TPA Manggar terkait pengelolaan sampah yang ada dan aksi yang diimplementasikan ke dalam kegiatan pengelolaan sampah dengan metode takakura serta kampanye lingkungan mengenai sampah dan dapat menjadi sebuah kegiatan positif dalam membudayakan kebiasaan baik dalam menjaga lingkungan. Sehingga, program ini dapat menjadi salah satu solusi alternatif dalam menanamkan kepedulian terhadap lingkungan terutama pengelolaan sampah kepada siswa di Sekolah Budi Mulia Balikpapan.

\section{METODE PELAKSANAAN}

\section{Persiapan Program}

Tahap ini dilakukan dengan tahap awal yaitu melakukan survei mitra yaitu Sekolah Budi Mulia Balikpapan untuk dapat melihat kondisi mitra sekaligus mengidentifikasi permasalahan yang terdapat di sana. Selanjutnya yaitu mempersiapkan semua peralatan dan perlengkapan yang dibutuhkan dalam menunjang pelaksanaan kegiatan.

\section{Pengenalan Program}

Pengenalan program pertama tim bertemu dengan guru-guru pengajar di Sekolah Budi Mulia seperti pada Gambar 1.

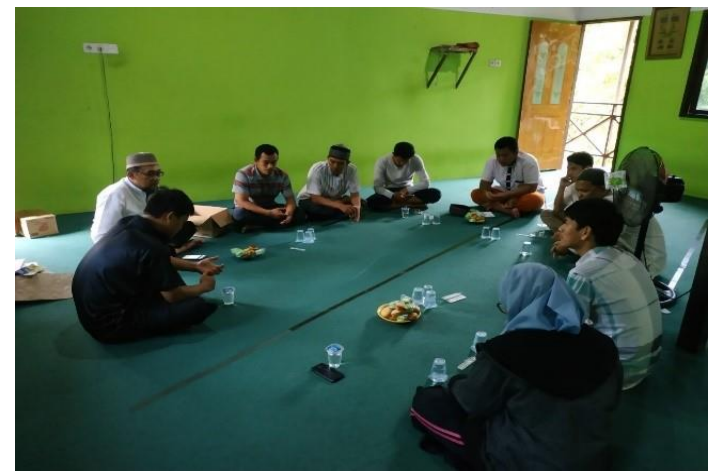

Gambar 1. Pengenalan program dengan guru pengajar di Sekolah Budi

Pertemuan tersebut bertujuan untuk memperkenalkan dan menjalin keakraban antara tim dan pihak guru yang menjadi target pengabdian, serta memaparkan program edukasi dan aksi pengelolaan sampah dengan melakukan pembuatan kompos menggunakan metode takakura. Tahap kedua, tim bertemu dengan para siswa Sekolah Budi Mulia untuk memperkenalkan program ini kepada siswasiswa yang menjadi target pengabdian.

\section{Pelaksanaan Program}

Pelaksanaan program dilakukan melalui dua tahap yaitu edukasi lingkungan dan aksi lingkungan. Pada tahap pelaksanaan program ini, tim volunteer melakukan controling secara bertahap kepada siswa-siswa yang menjadi target program sehingga program yang dilaksanakan dapat mencapai hasil yang maksimal, dengan harapan target pengabdian juga dapat membagi ilmu yang telah didapatkan sebagai wujud nyata seorang agen perubahan terutama dalam mengatasi permasalahan lingkungan dan pengelolaan sampah yang ada di sekitarnya.

\section{Edukasi Lingkungan}

Edukasi lingkungan terdiri dari 3 tahap. Tahap pertama, pesiapan alat dan bahan sebelum malaksanakan program yang dilakukan antara tim volunteer dan siswa-siswa yang menjadi target program. Tahap kedua, pembuatan poster lingkungan yang bertujuan untuk menumbuhkan 
kesadaran dan sebagai media mengkampanyekan permasalahan lingkungan yang ada. Tahap ketiga penjadwalan program dengan menyusun rencana kegiatan yang akan dilakukan agar dapat berjalan secara optimal. Dalam tahap ini juga terdapat pemberian materi dan post test kepada target sebagai parameter keberhasilan dari kegiatan yang telah dilaksanakan.

\section{Aksi Lingkungan}

Aksi pertama dilakukan di UPTD TPA Manggar dengan tujuan agar taget pengabdian bisa mendapatkan ilmu lebih banyak dengan terjun langsung ke lokasi pengelolaan sampah di tempat pembuangan akhir ini, kegiatan yang dilakukan yaitu pengolahan sampah. Tahap kedua perancangan konsep kegiatan yaitu diskusi yang dilakukan oleh tim volunteer dalam menyusun program aksi lingkungan agar lebih terkonsep dan tidak monoton sehingga target pengabdian tidak merasa bosan dengan kegiatan yang dilakukan. Setelah mendapatkan berbagai ilmu melalui kegiatan edukasi dan aksi lingkungan, tim volunteer dan target pengabdian kemudian mengimplementasikan ilmu yang didapatkan dengan menyelesaikan permasalah lingkungan di lingkungan Sekolah Budi Mulia yaitu dengan melakukan pembenahan lingkungan melalui penanganan dan pengolahan sampah seperti Gambar 2.

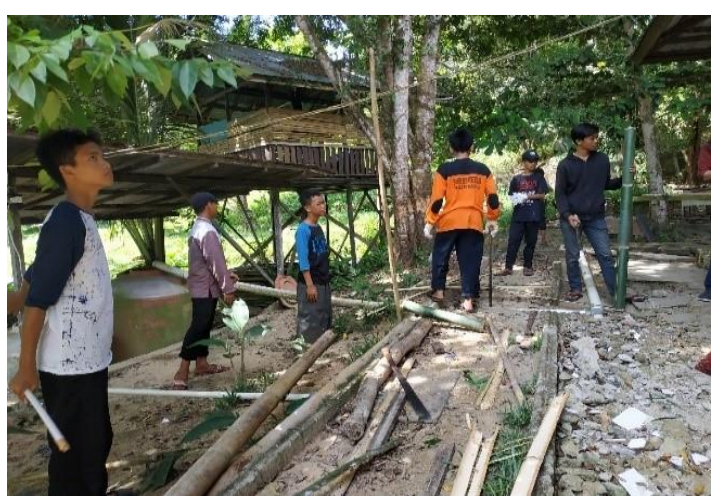

Gambar 2. Pengenalan program dengan guru pengajar di Sekolah Budi Mulia

\section{Monitoring dan Evaluasi}

Monitoring dan Evaluasi dalam pemberdayaan target pengabdian merupakan program pemantauan dengan mengukur parameter tingkat keberhasilan program pada mitra. Hal ini dapat dilihat dari hasil post test maupun pre test siswa-siswa yang menjadi target program selama kegiatan berlangsung. Adapun yang akan menjadi tolak ukur evaluasi ini yaitu dari tingkat kepahaman target pengabdian di Sekolah Budi Mulia dalam edukasi dan aksi lingkungan, serta kemampuan dalam mengaplikasikan program edukasi dan aksi dalam mengatasi permasalahan lingkungan yang ada di sekitarnya dan sebagai acuan untuk pengembangan edukasi kegiatan selanjutnya di Sekolah Budi Mulia Balikpapan

\section{HASIL DAN PEMBAHASAN}

\section{Solusi Teknologi Takakura}

Takakura menjadi solusi teknologi yang digunakan dalam pengelolaan sampah di Sekolah Budi Mulia Balikpapan. Metode takakura memiliki beberapa keunggulan dibandingkan dengan metode lain, yakni (1) praktis karena cocok digunakan dalam skala kecil (rumah tangga) tidak memerlukan lahan yang luas dalam pelaksanaannya, (2) mudah karena sampah yang dihasilkan dapat langsung diolah ditempat setiap waktu tanpa memerlukan perlakuan khusus, (3) tidak berbau karena prosesnya melalui proses fermentasi, bukan pembusukkan (Rezagama, 2015).

\section{Edukasi Lingkungan}

Sebelum memberikan edukasi dilakukan pendekatan terlebih dahulu sebagai upaya awal untuk memperkenalkan dan mendekatkan diri dengan siswa. Pada tahap pendekatan dengan siswa, tim juga memiliki maksud dan tujuan untuk mengabdi dan memperkenalkan program ini. Pada kesempatan itu pula tim mengamati serta melihat kemampuan siswa/siswi sebagai bekal pemberian materi dan pelaksanaan program. Pada tahap ini tim melakukan pre test kepada siswa-siswa yang menjadi target program dengan tujuan untuk mengetahui seberapa jauh pemahamannya mengenai pendidikan lingkungan dan pengelolaan sampah.

Selanjutnya, dilakukan kegiatan edukasi dengan memberikan pemberian materi mengenai permasalahan yang terkait dengan kondisi lingkungan di Sekolah Budi Mulia Balikpapan seperti materi mengenai isu lingkungan, pengetahuan tentang pengomposan, filtrasi dan pengelolaan lingkungan seperti pada Gambar 3. 


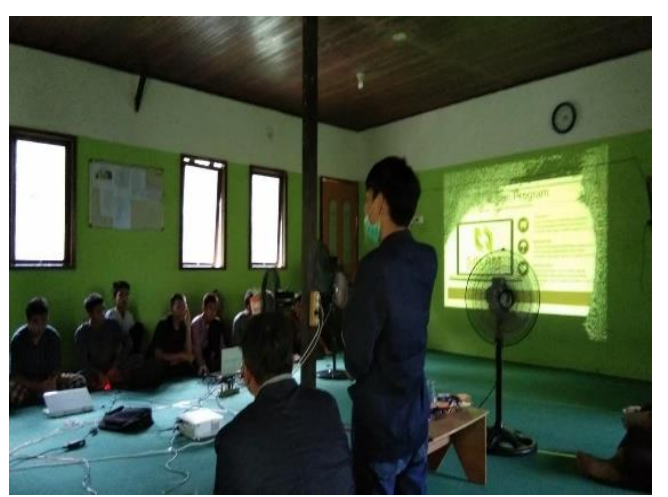

Gambar 3. Pemberian Materi Edukasi Takakura

Setelah pemberian materi, siswa Sekolah Budi Mulia diberikan tugas untuk mendesain poster bertema lingkungan seperti Gambar 4

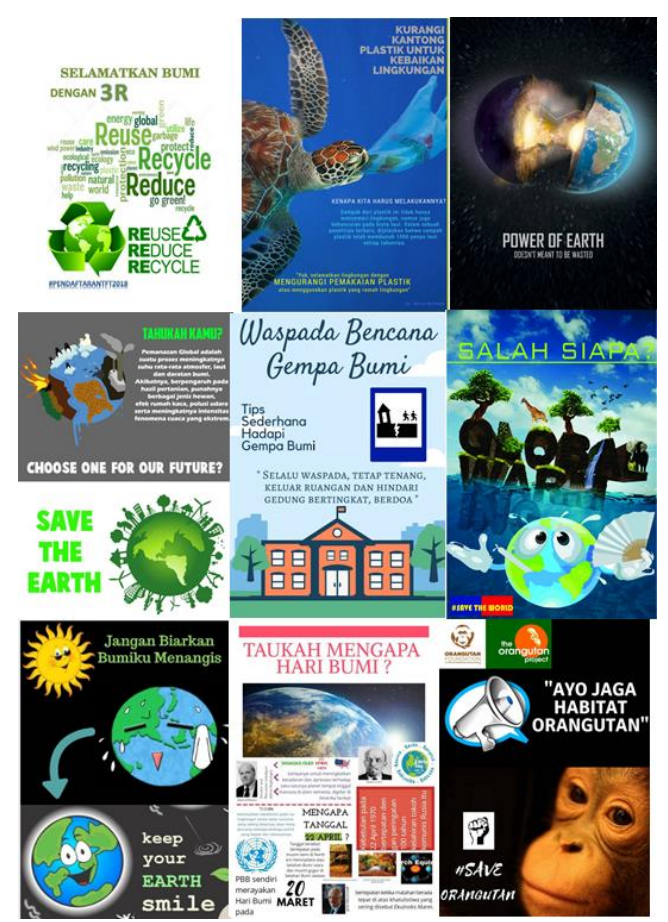

Gambar 4. Desain Poster Lingkungan

\section{Aksi Lingkungan}

Tahap pertama yang dilakukan mempersiapkan alat dan bahan serperti gergaji, pisau, paran, tali godam, kawat, paku, ember, karung, dan jaring, gayung (penakar air). Kemudian untuk bahannya adalah daun kering (sampah yang ada di sekolah), gula sebagai sumber makanan bakteri, Cairan EM4, air, dan sekam padi. Setelah itu, dilakukan pemotongan bambu menjadi bagian yang ditentukan degan tipis untuk membuat keranjang seperti seperti Gambar 5.

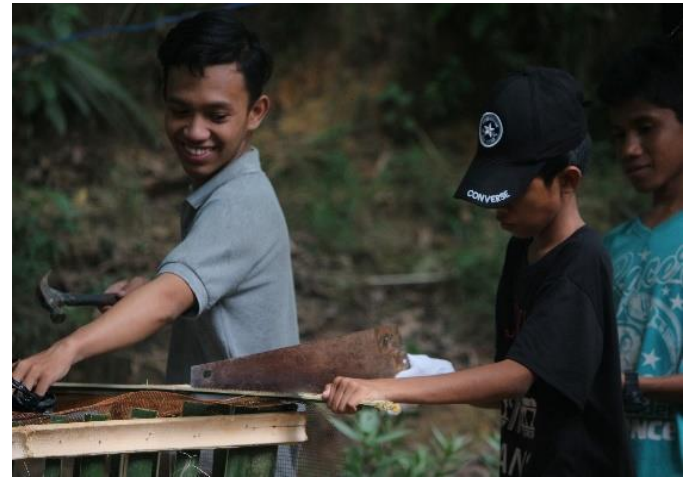

Gambar 5. Proses Pemotongan Bambu dalam Pembuatan Takakura

Kemudian, melakukan pembuatan keranjang sebagai media takakura seperti Gambar 6

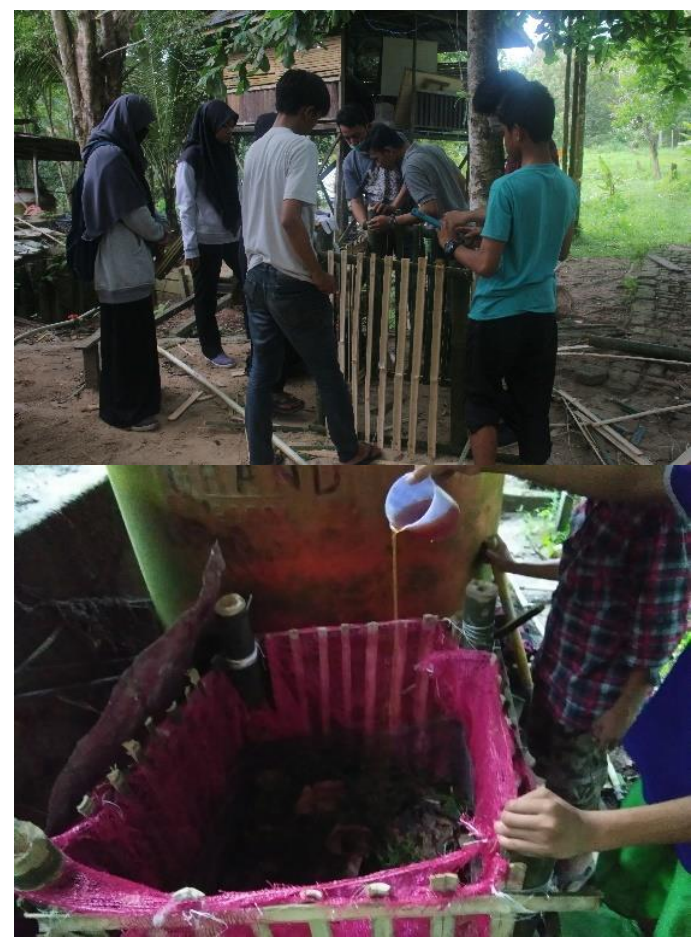

Gambar 6. Proses Pembuatan Takakura

Selanjutnya yaitu dengan membiakkan bakteri EM4 lalu mengumpulkan sampah yang berlokasi di Sekolah Budi Mulia. Setelah itu, mencacah sampah sayur menggunakan gunting hingga berukuran $\pm 2 \mathrm{~cm}$. Ukuran partikel menjadi pertimbangan yang penting pada tahap ini. Semakin kecil ukuran partikelnya, maka semakin baik untuk proses pengomposan. Sebab bakteri pengurai kompos akan lebih banyak yang tumbuh sehingga proses pengomposan akan lebih cepat terjadi. Setelah dicacah, bahan dicampur dengan aktivator yang digunakan yaitu EM4. Proses pencampuran menggunakan sekop kecil seperti Gambar 7. 


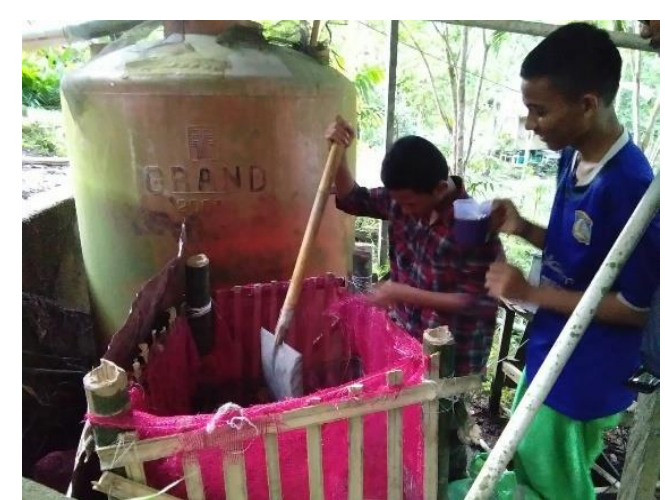

Gambar 7. Proses Pencacahan Sampah

Komposter dipersiapkan dengan menggunakan komposter takakura yang didesain dari keranjang berpori dan bambu tahan lama yang dilengkapi penutup. Bantalan sekam diletakkan dibawah dan diatas keranjang, berfungsi untuk menahan panas, mengatur kelembapan dan mencegah adanya lalat. Bantalan sekam dibuat dari jaring yang dijahit berisi sekam padi.

Setelah semuanya siap, bagian dasar keranjang diisi dengan bantalan sekam. Lalu bahan kompos yang telah dicampur diletakkan diatas bantalan sekam tersebut seperti gambar 8 . Setelah semuanya selesai, keranjang ditutup dengan penutupnya. Komposter disimpan di tempat yang teduh (memiliki sirkulasi udara yang lancar) serta terlindung dari sinar matahari.

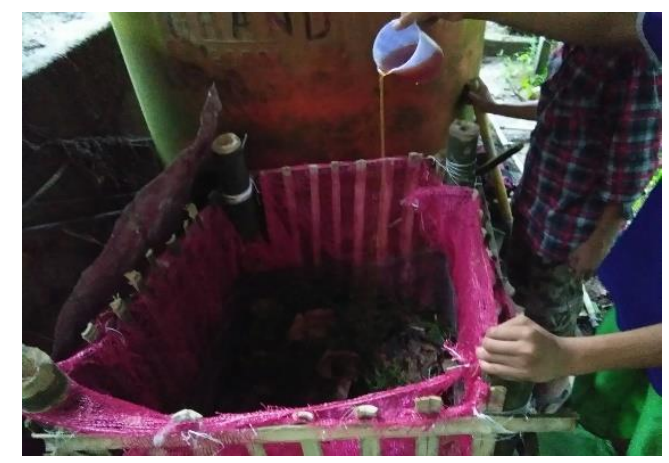

Gambar 8. Proses Pemberian Bakteri EM4

Lama waktu pengomposan sampah dalam kegiatan pengabdian ini ditetapkan berdasarkan penyusutan berat sampah dan memperhitungkan standar fisik kompos seperti tekstur yang menyerupai tanah. Sehingga dalam hal ini yang digunakan adalah daun kering yang bersifat kering sehingga menghasilkan kompos kering.

\section{Monitoring dan Evaluasi}

Monitoring dilakukan setiap sekali seminggu setelah 1 minggu semenjak pemberian bakteri EM4 sampai minggu ke 5 dengan melihat tingkat pengeringan dan penghancuran sampah seperti pada Gambar 9.

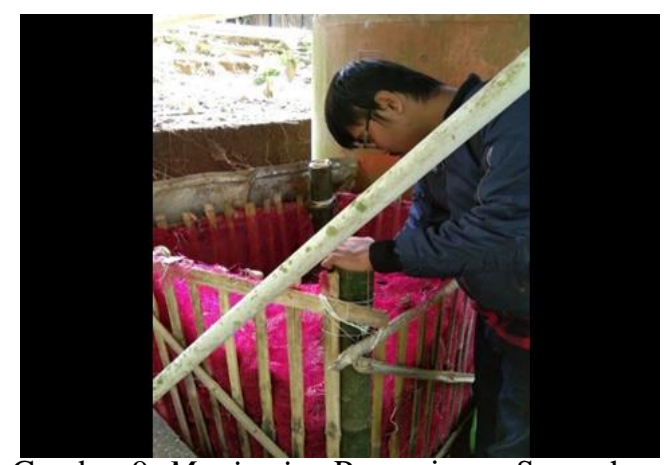

Gambar 9. Monitoring Pengeringan Sampah

Evaluasi dilakukan setelah mengolah nilai pre test dan post test dari siswa Budi Mulia Balikapapan. Berdasarkan pelaksanaan program yang telah dilakukan, didapatkan hasil data penilaian pre test siswa di Sekolah Budi Mulia Balikpapan. Rekapitulasi presentasi kepahamanan berdasarkan rentang nilai terdiri dari 4 yaitu sangat paham $(<80)$, paham $(<70)$, kurang paham $(<60)$, dan sangat kurang paham $(>60)$. Rekapitulasi dari banyaknya derajat kepahaman dapat dilihat yaitu:

Tabel 1. Rekapitulasi dari banyaknya derajat kepahaman

\begin{tabular}{|c|c|c|c|c|c|}
\hline No & $\begin{array}{l}\text { Pemahaman } \\
\text { Program } \\
\text { Tiap Bidang }\end{array}$ & $<80$ & $<70$ & $<60$ & $>60$ \\
\hline 1 & $\begin{array}{l}\text { Isu } \\
\text { Lingkungan }\end{array}$ & $81 \%$ & $14 \%$ & $5 \%$ & $0 \%$ \\
\hline 2 & Kompos & $72 \%$ & $27 \%$ & $0 \%$ & $0 \%$ \\
\hline 3 & Filtrasi & $72 \%$ & $18 \%$ & $10 \%$ & $0 \%$ \\
\hline 4 & $\begin{array}{l}\text { Pengelolaan } \\
\text { Lingkungan }\end{array}$ & $100 \%$ & $0 \%$ & $0 \%$ & $0 \%$ \\
\hline
\end{tabular}

Jumlah soal 20 soal dengan rincian sebagai berikut:

Tabel 2. Kategori Bidang Soal

\begin{tabular}{clc}
\hline No & $\begin{array}{l}\text { Pemahaman Program } \\
\text { Tiap Bidang }\end{array}$ & No soal \\
\hline 1 & Isu Lingkungan & $1-5$ \\
2 & Kompos & $6-14$ \\
3 & Filtrasi & $15-19$ \\
4 & Pengelolaan Lingkungan & $20-21$ \\
\hline
\end{tabular}


Grafik presentase kepahaman tiap bidang pasca kegiatan melalui kegiatan post test yang dibandingkan dengan nilai saat kegiatan pre test dengan hasil sebagai berikut:

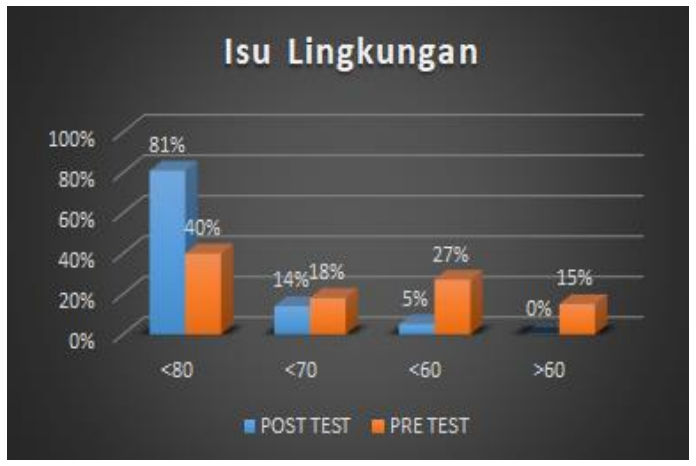

Gambar 10. Presentase Nilai Soal Isu Lingkungan

Berdasarkan Gambar 10, siswa yang menjadi target pemberdayaan program ini mengalami kenaikan post test pada pengetahuan mengenai isu lingkungan dengan nilai rata-rata 80 sebanyak $81 \%$.

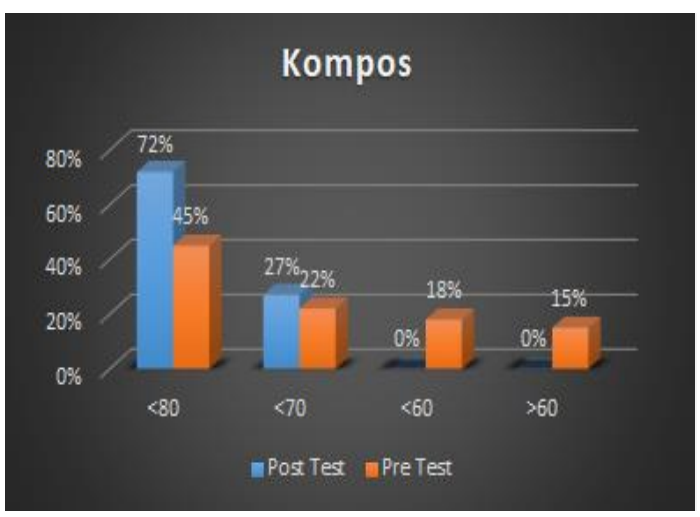

Gambar 11. Presentase Nilai Soal Kompos

Berdasarkan Gambar 11, siswa yang menjadi target pemberdayaan program ini mengalami kenaikan post test pada pengetahuan mengenai kompos dengan nilai rata-rata 80 sebanyak $72 \%$.

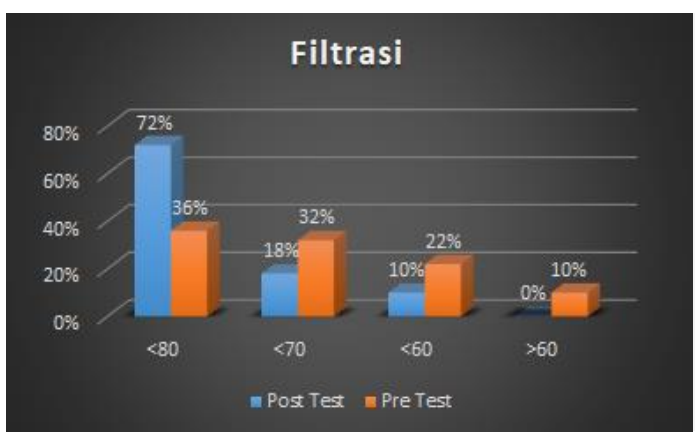

Gambar 12. Presentase Nilai Soal Filtrasi
Berdasarkan Gambar 12, siswa yang menjadi target pemberdayaan program ini mengalami kenaikan post test pada pengetahuan mengenai filtrasi dengan nilai rata-rata 80 sebanyak $72 \%$.

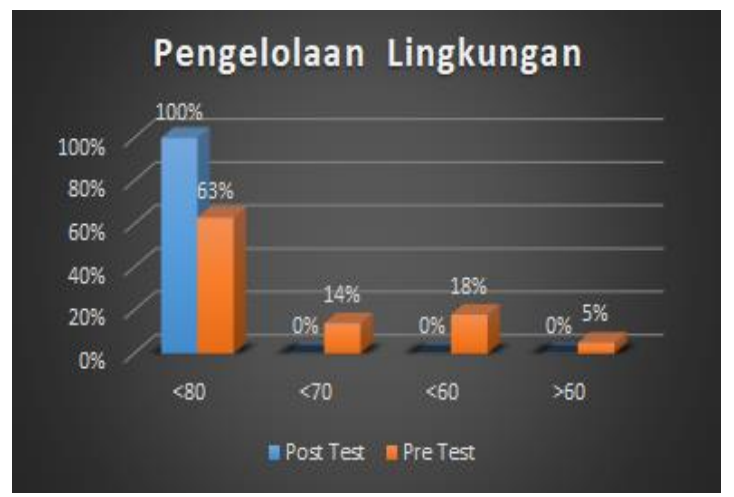

Gambar 13. Presentase Nilai Soal Pengelolaan Lingkungan

Berdasarkan Gambar 13 di atas siswa yang menjadi target pemberdayaan program ini mengalami kenaikan post test pada pengetahuan mengenai pengelolaan dengan nilai rata-rata 80 sebanyak $100 \%$.

Setelah dilakukannya monitoring selama 5 minggu pasca pelaksanaan program pemberdayaan ini, Siswa di Sekolah Budi Mulia dapat melakukan pengelolaan sampah dengan metode takakura secara mandiri. Berdasarkan hasil dari kegiatan pre test dan post test yang telah dilakukan untuk mengukur tingkat kepahaman siswa dalam hal kepedulian lingkungan, Siswa yang menjadi target pemberdayaan ini mengalami kenaikan nilai yang cukup signifikan.

\section{SIMPULAN DAN SARAN}

Kegiatan pemberdayaan sekolah Budi Mulia Balikpapan melalui edukasi dan aksi pembuatan kompos dengan metode TAKAKURA berhasil memberi pengetahuan kepada siswa dalam pengelolaan sampah dengan metode TAKAKURA. Selain itu melaui kegiatan edukasi dan aksi pembuatan kompos juga berhasil menyadarkan pentingnya arti menjaga kualitas lingkungan hidup dan pengelolaan sampah yang baik di Sekolah Budi Mulia Balikpapan.

Berdasarkan hasil pre test dan post test terdapat peningkatan pemahaman target pengabdian berdasarkan grafik dan tabel tingkat pemahaman peserta pemberdayaan, baik dari materi mengenai isu lingkungan, pengetahuan 
tentang pengomposan, filtrasi dan pengelolaan lingkungan. Sehingga, dapat disimpulkan bahwa kegiatan edukasi dan aksi lingkungan dengan metode takakura dapat menjadi metode yang efektif dalam peningkatan pemahaman dan kepedulian target sasaran terhadap lingkungan di sekitarnya.

Kegiatan pemberdayaan di Sekolah Budi Mulia ini dapat menjadi salah satu percontohan bagi pemuda dan pemudi di Indonesia untuk melakukan kegiatan positif dan bermanfaat yang serupa terutama dalam menumbuhkan kepedulian dalam menjaga lingkungan.

Selain itu juga dapat menjadi sumber referensi dalam pengembangan kegiatan pengabdian lainnya.

\section{UCAPAN TERIMAKASIH}

Adapun dalam pembuatan jurnal ini ada beberapa pihak yang membantu dalam penyusunannya, maka kami penulis mengucapkan terimakasih atas bantuannya dalam proses penulisan jurnal.

1. Rektor Institut Teknologi Kalimantan

2. Dosen Pembimbing
3. Orang tua

4. Siswa dan guru Sekolah Budi Mulia Balikpapan

5. Volunteer Program Edukasi dan Aksi Lingkungan

6. Serta berbagai pihak yang telah membantu dan tidak dapat kami sebutkan satu persatu

\section{DAFTAR PUSTAKA}

Laporan Kinerja Instansi Pemerintah Dinas Lingkungan Hidup Kota Balikpapan pada tahun 2017

Rahmah, Nur Lailatul. (2014). Pembuatan kompos limbah log jamur tiram: Kajian konsnetrasi kotoran kambing dan EM4 serta waktu pembalikan. Jurnal teknologi pertanian; 15 (1): $59-66$.

Rezagama, Arya. (2015). Studi optimasi takakura dengan penambahan sekam dan bekatul. Jurnal presipitasi; 12 (2): 66 - 70 .

Susanto, R. (2002). Pertanian Organik: Menuju Pertanian Alternatif dan Berkelanjutan. Penerbit Kansius. Yogyakarta.

Undang-undang Nomor 32 Tahun 2009 